\title{
ANALISIS DAMPAK STRATEGI KOMUNIKASI NON VERBAL
}

\author{
Hadianto Ego Gantiano \\ Institut Agama Hindu Negeri Tampung Penyang, Palangka Raya, hadianto@iahntp.ac.id
}

\begin{abstract}
Abstrack
Non-verbal communication is a process of communication where the message is conveyed not by using words. For example, only by using gestures, body language, facial expressions and eye contact, the use of objects such as clothing, haircuts and so on, symbols and ways of speaking such as intonation, emphasis, sound quality, emotional style and speaking style. Even so, experts in the field of non-verbal communication usually use the definition of "not using words" with katat, and do not equate non-verbal communication with non-verbal communication. For example sign and written languages are not considered non-verbal communication because they use words, while intonation and speaking style are classified as non-verbal communication. Non-verbal communication is also different from talking classified as non-verbal communication. Non-verbal communication is also different from subconscious communication, which can be verbal or non verbal communication. In this case the most common is the use of clothing, where people are often judged by the type of clothing they use, although this is considered wrong for stereotypes. For example, people often prefer other people who have interesting ways of dressing. Also in job interviews someone who is dressed attractively is more likely to get a job than those who are not.
\end{abstract}


I. PENDAHULUAN

Komunikasi non

verbal adalah salah satu jenis komunikasi yang paling sering dibicarakan karena tidak semua orang telah mengenal komunikasi ini dan peranannya dalam berbagai bidang kehidupan kita. Walaupun secara alamiah kita memberikan atau melakukan komunikasi verbal terhadap lawan bicara kita, akan tetapi tidak serta merta kita menjadi ahli atau menguasai kemampuan untuk melakukan komunikasi non verbal, terlebih lagi dalam komunikasi bisnis. Oleh karena itulah, dengan mengetahui apa saja pengaruh komunikasi non verbal terhadap komunikasi bisnis, kita bisa lebih berhati-hati saat melakukan komunikasi non verbal dan tentunya mengetahui apa saja pengaruhnya bagi keberhasilan dalam berkomunikasi. Komunikasi non verbal ( non verbal communicarion) menempati porsi penting. Banyak komunikasi verbal tidak efektif hanya karena komunikatornya tidak menggunakan komunikasi non verbal dengan baik dalam waktu bersamaan. Melalui komunikasi non verbal, orang bisa mengambil suatu kesimpulan mengenai suatu kesimpulan tentang berbagai macam persaan orang, baik rasa senang, benci, cinta, kangen dan berbagai macam perasaan lainnya. Kaitannya dengan dunia bisnis, komunikasi non verbal bisa membantu komunikator untuk lebih memperkuat pesan yang disampaikan sekaligus memahami reaksi komunikan saat menerima pesan. (Gantiano, 2019)

Pengertian lain yang lebih spesifik disampaikan oleh Deddy Mulyana dalam bukunya. Ia menyatakan bahwa komunikasi verbal adalah komunikasi yang menggunakan perangkat simbol, dengan aturan untuk mengkombinasikan simbol - simbol tersebut, yang digunakan dan dipahami suatu komunitas. Dalam definisi tersebut ia juga menekankan bahwa simbol dengan aturan ini merupakan bentuk paling sederhana dari bahasa (2005:17). Para ahli di bidang komunikasi nonverbal biasanya menggunakan definisi "tidak menggunakan kata" dengan ketat, dan tidak menyamakan komunikasi nonverbal dengan komunikasi non lisan. Contohnya, bahasa isyarat dan tulisan tidak dianggap sebagai komunikasi nonverbal karena menggunakan kata, 
sedangkan intonasi dan gaya berbicara tergolong sebagai komunikasi nonverbal. Komunikasi nonverbal juga berbeda dengan komunikasi bawah sadar, yang dapat berupa komunikasi verbal ataupun nonverbal.

Komunikasi objek yang paling umum adalah penggunaan pakaian. Orang sering dinilai dari jenis pakaian yang digunakannya, walaupun ini dianggap termasuk salah satu bentuk stereotipe. Misalnya orang sering lebih menyukai orang lain yang cara berpakaiannya menarik. Selain itu, dalam wawancara pekerjaan seseorang yang berpakaian cenderung lebih mudah mendapat pekerjaan daripada yang tidak. Contoh lain dari penggunaan komunikasi objek adalah seragam. Komunikasi non verbal merupakan salah satu proses komunikasi dimana pesan disampaikan tidak dengan menggunakan kata-kata. Misalnya saja hanya dengan menggunakan gerak isyarat, bahasa tubuh, ekspresi wajah dan kontak mata, penggunaan objek seperti pakaian, potongan rambut dan sebagainya, simbol-simbol serta cara berbicara seperti intonasi, penekanan, kualitas suara, gaya emosi dan gaya berbicara.
Meskipun begitu, para ahli dibidang komunikasi non verbal biasanya menggunakan definisi "tidak menggunakan kata" dengan katat, dan tidak menyamakan komunikasi non verbal dengan komunikasi non lisan. Contohnya bahasa isyarat dan tulisan tidak dianggap sebagai komunikasi non verbal karena menggunakan kata, sedangkan intonasi dan gaya berbicara tergolong sebagai komunikasi non verbal. Komunikasi non verbal juga berbeda berbicara tergolong sebagai komunikasi non verbal. Komunikasi non verbal juga berbeda dengan komunikasi bawah sadar, yang dapat berupa komunikasi verbal ataupun non verbal.

\section{PEMBAHASAN}

Komunikasi nonverbal memainkan peranan yang sangat penting dalam kehidupan kita ketika kita berkomunikasi dengan orang-orang yang kita temui. Komunikasi nonverbal adalah sebuah proses menggunakan pesan-pesan tanpa kata untuk menyamakan makna. Studi ilmiah pertama tentang komunikasi nonverbal dapat kita ketahui melalui buku Charles Darwin, sang penemu teori evolusi. Dalam bukunya ia berpendapat bahwa semua mamalia menunjukkan emosi melalui raut wajah. 
Emosi merupakan salah satu bentuk komunikasi nonverbal yang menggambarkan pentingnya arti komunikasi apapun konteksnya.

\subsection{Strategi Komunikasi}

Komunikasi memiliki peranan yang sangat vital dalam kehidupan kita, baik dalam membentuk hubungan sosial maupun hubungan interpersonal. Komunikasi terjadi dalam berbagai konteks komunikasi seperti komunikasi intrapersonal, komunikasi interpersonal atau komunikasi antar pribadi, komunikasi kelompok, serta komunikasi massa.

Telah disebutkan di atas bahwa untuk mencapai komunikasi yang efektif diperlukan suatu strategi komunikasi yang baik. Strategi merujuk pada pendekatan komunikasi menyeluruh yang akan diambil dalam rangka menghadapi tantangan yang akan dihadapi selama berlangsungnya proses komunikasi. Berbagai pendekatan dapat dilakukan tergantung pada situasi dan kondisi, misalnya pendekatan kesehatan masyarakat, pendekatan pasar bebas, model pendidikan, atau pendekatan konsorsium. Salah satu dari pendekatan-pendekatan itu dapat dianggap sebagai dasar dari sebuah strategi dan berfungsi sebagai sebuah kerangka kerja untuk perencanaan komunikasi selanjutnya. Sebuah strategi hendaknya menyuguhkan keseluruhan arah bagi inisiatif, kesesuaian dengan berbagai sumber daya yang tersedia, meminimalisir resistensi, menjangkau kelompok sasaran, dan mencapai tujuan inisiatif komunikasi.

Dari uraian singkat di atas, apakah yang dimaksud dengan strategi? Menurut Onong Uchjana Effendy (1984 : 35), intinya strategi adalah perencanaan atau planning dan manajemen untuk mencapai suatu tujuan yang hanya dapat dicapai melalui taktik operasional. Sebuah strategi komunikasi hendaknya mencakup segala sesuatu yang dibutuhkan untuk mengetahui bagaimana berkomunikasi dengan khalayak sasaran. Strategi komunikasi mendefinisikan khalayak sasaran, berbagai tindakan yang akan dilakukan, mengatakan bagaimana khalayak sasaran akan memperoleh manfaat berdasarkan sudut pandangnya, dan bagaimana khalayak sasaran yang lebih besar dapat dijangkau secara lebih efektif.

Sementara itu, menurut Mohr dan Nevin mendefinisikan sebuah strategi komunikasi sebagai penggunaan kombinasi faset-faset komunikasi dimana termasuk di dalamnya frekuensi komunikasi, formalitas komunikasi, isi komunikasi, saluran komunikasi (Kulvisaechana, 2001 : 17-18) 
Dalam dunia bisnis, tujuan strategi pada umumnya adalah untuk menentukan dan mengkomunikasikan gambaran tentang visi perusahaan melalui sebuah sistem tujuan utama dan kebijakan. Strategi menggambarkan sebuah arah yang didukung oleh berbagai sumber daya yang ada. Sementara itu, menurut R. Wayne Pace, Brent D. Peterson, dan M. Dallas Burnett menyatakan bahwa strategi komunikasi memiliki 3 (tiga) tujuan, yaitu (Effendy, 1984 : 35-36) :

1. To secure understanding - memastikan pesan diterima oleh komunikan.

2. To establish acceptance - membina penerimaan pesan.

3. To motivate action - kegiatan yang dimotivasikan.

Strategi komunikasi yang dilakukan bersifat makro dan proses strategi komunikasi berlangsung secara vertikal piramidal.

Telah disebutkan sebelumnya bahwa dalam komunikasi terdapat beberapa komponen yang mendukung berjalannya proses komunikasi. Berbagai literatur menyatakan bahwa terdapat sebuah paradigma atau formula yang sering digunakan untuk mengetahui komponenkomponen komunikasi. Paradigma atau formula itu adalah paradigma atau formula yang dikemukakan oleh Harold

D.
Lasswell. Melalui paradigma atau formula yang telah dirumuskannya, Harold D. Lasswell mencoba untuk memberikan penjelasan kepada kita bahwa untuk mengetahui apa saja yang menjadi komponen-komponen komunikasi maka harus menjawab beberapa pertanyaan seperti Who Says What In What Channel To Whom With What Effect.

Formula Lasswell ini tidak luput dari kritik yang salah satunya datang dari Gerhard Maletzke. Maletzke menyatakan bahwa paradigma atau formula yang dikemukakan oleh Lasswell tidak mempertimbangkan hal yang sangat penting yakni tujuan yang akan dicapai oleh komunikator. Tidak sedikit ahli yang menyatakan bahwa tujuan komunikasi hendaknya dinyatakan secara eksplisit karena tujuan komunikasi berkaitan erat dengan khalayak sasaran dalam strategi komunikasi.

Dalam strategi komunikasi perlu mempertimbangkan berbagai komponen dalam komunikasi karena komponenkomponen itulah yang mendukung jalannya proses komunikasi yang sangat rumit. Selain komponen-komponen komunikasi, hal lain yang juga harus menjadi bahan pertimbangan adalah faktor-faktor yang mempengaruhi komunikasi serta hambatan-hambatan komunikasi. 
Berikut diulas tentang 4 (empat) komponen utama komunikasi yang menjadi pusat kajian dalam strategi komunikasi :

\subsubsection{Komunikator}

Komunikator merupakan pihak yang menjalankan proses strategi komunikasi. Untuk menjadi komunikator yang baik dan apat dipercaya oleh komunikate atau khalayak sasaran, maka komunikator harus memiliki daya tarik serta kredibilitas

\subsubsection{Daya Tarik}

Adalah manusiawi jika komunikate atau khalayak sasaran yang cenderung merasa memiliki kesamaan dengan komunikator akan mengikuti apa yang diinginkan oleh komunikator. Dalam hal ini, komunikate atau khalayak sasaran melihat komunikator memiliki daya tarik tertentu sehingga khalayak sasaran bersedia untuk merubah pikiran, sikap, pendapat, dan perilakunya sesuai dengan yang diinginkan oleh komunikator. Daya tarik juga dapat dilihat dari penampilan komunikator.

\subsubsection{Kredibelitas}

Selain daya tarik, kredibilitas komunikator juga menjadi alasan kuat khalayak sasaran atau komunikate bersedia merubah pikiran, sikap, pendapat, dan perilakunya sesuai dengan isi pesan yang disampaikan oleh komunikator. Kredibilitas komunikator adalah faktor yang membuat khalayak sasaran percaya kepada apa yang disampaikan oleh komunikator dan mengikuti kemauan komunikator. Komunikator yang benar-benar menguasai permasalahan dan memiliki penguasaan bahasa yang baik cenderung dipercaya oleh khalayak sasaran.

\subsubsection{Pesan Komunikasi}

Pesan yang disampaikan oleh komunikator kepada khalayak sasaran atau komunikate dalam strategi komunikasi pastinya memiliki tujuan tertentu. Tujuan inilah yang menentukan teknik komunikasi yang akan dipilih dan digunakan dalam strategi komunikasi. Dalam strategi komunikasi, perumusan pesan yang baik dengan mempertimbangkan situasi dan kondisi khalayak sangatlah penting 
Pesan yang dirumuskan oleh komunikator hendaknya tepat mengenai khalayak sasaran. Menurut Soeganda Priyatna (2004), terdapat syarat-syarat yang harus dipenuhi agar pesan yang disampaikan dapat mengena kepada khalayak sasaran yaitu :

- Umum - pesan disampaikan adalah pesan yang bersifat umum dan mudah dipahami oleh khalayak sasaran

- Jelas - pesan yang disampaikan harus jelas dan tidak menimbulkan salah penafsiran

- Bahasa jelas - bahasa yang digunakan dalam proses penyampaian pesan hendaknya menggunakan bahasa yang jelas dan sesuai dengan khalayak sasaran serta tidak menggunakan istilah-istilah yang tidak dimengerti oleh khalayak sasaran (Baca juga : Bahasa sebagai Alat Komunikasi).

- Positif - pesan yang disampaikan kepada khalayak sasaran dilakukan dengan caracara yang positif sehingga mendatangkan rasa simpati dari khalayak sasaran

- Seimbang - pesan yang disampaikan kepada khalayak sasaran disampaikan dengan seimbang, tidak melulu mengungkapkan sisi positif namun juga sisi negative agar khalayak sasaran dapat menerimanya dengan baik

- Sesuai- pesan yang disampaikan hendaknya disesuaikan dengan keinginan khalayak sasaran.

\subsection{Prinsip, Fungsi dan Jenis Strategi} Komunikasi Non Verbal

Komunikasi nonverbal lebih tua daripada komunikasi verbal. Kita lebih awal melakukannya, kerena hingga usia kira-kira 18 bulan, kita secara total bergantung pada komunikasi nonverbal seperti sentuhan, senyuman, pandangan mata, dan sebagainya. Maka, tidaklah mengherankan ketika kita ragu pada seseorang, kita lebih percaya pada pesan nonverbalnya. Orang yang terampil membaca pesan nonverbal orang lain disebut intuitif, sedangkan yang terampil mengirimkannya disebut ekspresif. Secara sederhana, pesan nonverbal adalah semua isyarat yang bukan kata-kata. Menurut Larry A. Samovar dan Richard E. Porter, komunikasi nonverbal mencakup semua rangsangan (kecuali rangsangan verbal) dalam suatu setting komunikasi, yang dihasilkan oleh individu dan penggunaan lingkungan oleh individu, yang mempunyai nilai pesan potensial bagi pengirim atau penerima. 


\subsubsection{Prinsip Komunikasi Non Verbal}

Komunikasi nonverbal bekerja berdasarkan beberapa prinsip. Menurut Dale G. Leathers, prinsip-prinsip komunikasi nonverbal adalah sebagai berikut (Rakhmat, $2001: 287-289)$ :

1. Komunikasi nonverbal sangat menentukan makna dalam komunikasi interpersonal atau komunikasi antar pribadi.

2. Komunikasi nonverbal lebih efektif dalam menyampaikan perasaan dan emosi dibandingkan dengan komunikasi verbal.

3. Komunikasi nonverbal lebih efektif dalam menyampaikan makna dan maksud yang relative bebas dari penipuan, distorsi dan kerancuan.

4. Komunikasi nonverbal lebih efisien dibandingkan dengan komunikasi verbal.

5. Komunikasi nonverbal merupakan sarana sugesti yang paling tepat.

6. Komunikasi nonverbal bersifat metakomunikatif yang sangat diperlukan dalam rangka mencapai komunikasi yang berkualitas tinggi.

Inti utama proses komunikasi adalah penyampaian pesan oleh komunikator di satu pihak dan penerimaan pesan oleh komunikan di pihak lainnya. Kadar yang paling rendah dari keberhasilan komunikasi diukur dengan pemahaman komunikan pada pesan yang diterimanya. Pemahaman komunikan terhadap isi pesan atau makna pesan yang diterimanya merupakan titik tolak untuk terjadinya perubahan pendapat, sikap, dan tindakan. Pesan komunikasi secara garis besar dapat dibedakan menjadi dua ketegori, yakni pesan verbal dan pesan nonverbal. Pesan verbal adalah pesan yang berupa bahasa, baik yang diungkapakan melalui kata-kata maupun yang dituangkan dalam bentuk rangkaian kalimat tulisan. Pesan nonverbal adalah pesan yang berupa isyarat atau lambang-lambang selain lambang bahasa.

Sebagaimana kata-kata, kebanyakan isyarat nonverbal juga tidak universal. Melainkan terikat oleh budaya, jadi dipelajari, bukan bawaan. Sedikit isyarat nonverbal yang merupajan bawaan. Kita semua lahir dan mengetahui bagaimana tersenyum, namun kebanyakan ahli sepakat bahwa di mana, kapan, dan kepada siapa kita menunjukkan emosi ini dipelajari, dan karenanya dipengaruhi oleh konteks dan budaya. Kita belajar menatap, memberi isyarat, memakai parfum, menyentuh berbagai bagiann tubuh orang lain, dan bahkan kapan kita diam. Cara kita bergerak dalam ruang ketika berkomunikasi dengan orang lain didasarkan terutama pada respons 
fisik dan emosional terhadap rangsangan lingkungan. Smentara kebanyakan perilaku verbal kita bersifat eksplisit dan diproses secara kognitif, perilaku nonverbal kita bersifat spontan, ambigu, sering berlangsung cepat, dan di luar kesadaran dn kendali kita. Karena itulah Edward T. Hall menamai bahasa nonverbal ini sebagai "bahasa diam" (silent language) dan "dimensi tersembunyi" (hidden dimension). Disebut diam dan tersembunyi, karena pesan-pesan nonverbal tertanam dalam konteks komunikasi. Selain isyarat situasional dan relasional dalam transaksi komunikasi, pesan nonverbal memberi kita isyarat-isyarat kontekstual. Bersama isyarat verbal dan isyarat kontekstual, pesan nonverbal membantu kita menafsirkan seluruh makna pengalaman komunikasi.

\subsubsection{Fungsi Komunikasi Non Verbal}

Fungsi utama komunikasi nonverbal adalah untuk mengirimkan makna melalui penguatan, berlawanan dengan komunikasi verbal, serta mengganti lambang-lambang verbal. Komunikasi nonverbal juga digunakan untuk mempengaruhi orang lain dan mengatur alur percakapan. Lebih lengkapnya, fungsi-fungsi komunikasi nonverbal adalah sbagai berikut :
- Komunikasi nonverbal mengirimkan makna.

- Komunikasi nonverbal mempengaruhi orang lain.

- Komunikasi nonverbal mengatur alur percakapan.

- Komunikasi nonverbal berdampak pada hubungan.

- Komunikasi nonverbal mengekspresikan identitas kita.

Sementara itu, menurut Argyle (1988) perilaku nonverbal memiliki fungsi-fungsi sebagai berikut :

- Mengekspresikan emosi dalam artian bahwa emosi pada umumnya diekspresikan melalui wajah, tubuh, dan suara.

- Mengirimkan sikap - sikap interpersonal yaitu membentuk dan mengelola hubungan.

- Presentasi diri atau menampilkan kepribadian seseorang kepada orang lain.

- Melengkapi pembicaraan dengan tujuan untuk mengelola umpan balik, perhatian, dan lain-lain - vokalisasi dan perilaku nonverbal adalah sesuai dengan ujaran percakapan

- Ritual- menggunakan salam, gerakan tangan, dan lain-lain. 
Dalam komunikasi interpesonal, pesan nonverbal memiliki fungsi-fungsi : (1) Repetisi, yakni mengulang kembali gagasan yang sudah dinyatakan secara verbal. Misalnya, setelah kita menjelaskan penolakan kita, kita menggelengkan kepala berkali-kali, (2) Substitusi, yakni menggantikan lambang-lambang verbal. Misalnya, tanpa sepatah katapun Anda berkata, Anda dapat menunjukkan persetujuan dengan mengangguk-angguk, (3) Kontradiksi, yakni menolak pesan verbal atau memberikan makna terhadap pesan verbal. Misalnya, Anda memuji prestasi kawan Anda dengan mencibirkan bibir Anda, "Hebat, kau memang hebat," (4) Komplemen, yakni melengkapi dan memperkaya makna pesan verbal. Misalnya, air muka Anda menunjukkan tingkat penderitaan yang tidak terungkap dengan kata-kata, (5) Aksentuasi, yakni menegaskan pesan verbal atau menggarisbawahinya. Misalkan, Anda mengungkapkan betapa jengkelnya Anda dengan memukul meja.

Pesan nonverbal dapat berupa pesan kinesis, pesan prosemik, pesan artifaktual, pesan paralinguistik, dan pesan sentuhan serta bau-bauan. Pesan kinesis adalah pesan nonveral denagn menggunakan gerakan tubuh yang terdiri dari tiga komponen utama: pesan fasial, pesan gestural, dan pesan postural. Pesan fasial berupa ekspresi wajah (air muka) dalam menyampaikan makna tertentu; pesan gestural berupa gerakan sebagian anggota badan seperti mata dan tangan; sedangkan pesan postural berkenaan denagn keseluruhan anggota badan. Postur TNI ketika berdiri di hadapan atasannya akan berbeda dengan postur anak sekolah ketika berhadapan dengan gurunya. Pesan proksemik disampaikan melalui pengaturan jarak dan ruang. Jarak tempat di antara dua orang yang sedang berkomunikasi dapat menginformasikan kepada kita, bagaimana tingkat keakraban diantara keduanya dan bagaimana tingkat keformalan komunikasinya. Jarak duduk antara Anda dan kekasih Anda ketika berbicara di malam Minggu akan berbeda dengan jarak duduk Anda dengan Dosen "Killer" Anda yang membuat Anda tidak lulus ujian.

Pesan artifaktual diungkapkan melalui penampilan (tubuh, pakaian, dan kosmetik). Pakaian tertentu berhubungan denagn perilaku tertentu. Pada umumnya, pakaian kita pergunakan untuk menyampaikan identitas kita, untuk mengungkapkan kepada orang lain "Siapa Kita". Pesan Paralinguistik adalah pesan nonverbal yang berhubungan dengan cara mengungkapkan pesan verbal. Satu pesan verbal yang sama dapat menyampaikan arti 
yang berbeda bila diucapkan dengan cara yang berbeda. Pesan paralinguistik terdiri dari, antara lain, nada, kualitas suara, volume, kecepatan, dan ritme.

Pesan sentuhan dan baubauan (tactile and olfactory message) termasuk pesan nonverbal nonvisual dan nonvokal. Pesan ini hanya dapat ditangkap melalui indera peraba dan indera penciuman. Kesimpulannya, pesan nonverbal sangat berpengaruh terhadap keefektifan komunikasi interpersonal. Pesan nonverbal akan mampu mengungkapkan hal yang tidak bisa atau tidak mau diungkapkan dengan pesan verbal.

Komunikasi nonverbal memiliki beberapa manfaat yang sangat penting dalam kaitannya dengan komunikasi verbal. Berikut adalah beberapa manfaat komunikasi nonverbal menurut Mark L. Knapp (1972), yaitu :

- Repetisi terjadi manakala pesan yang sama dikirim secara verbal dan nonverbal.

- Aksentuasi maksudnya adalah bahwa adanya penggunan petunjuk nonverbal untuk menguatkan pesan yang dikirimkan.

- Komplemen maksdunya adalah bahwa kode-kode nonverbal dan verbal menambah makna bagi satu sama lain.
- Kontradiksi maksudnya adalah bahwa terjadi konflik antara pesan verbal dan pesan nonverbal.

- Substitusi maksudnya adalah bahwa kode-kode nonverbal digunakan untuk menggantikan lambang-lambang verbal.

Agar kita memiliki kompetensi dalam komunikasi nonverbal, maka kita harus mampu mengidentifikasi serta menerapkan berbagai strategi untuk meningkatkan kompetensi dalam dua hal yaitu kompetensi dalam mengirimkan pesan-pesan nonverbal dan kompetensi dalam menginterpretasi pesan-pesan nonverbal.

Untuk memperkaya kompetensi kita mengenai encoding pesan-pesan nonverbal, maka kita harus meningkatkan kepedulian kita terhadap pesan yang kita kirimkan dan kita terima, serta konteks dimana komunikasi tersebut terjadi. Komunikasi nonverbal adalah komunikasi yang multi saluran sehingga sangat penting bagi kita untuk peduli bahwa petunjuk komunikasi nonverbal dapat melengkapi, meningkatkan, atau bahkan bertolakbelakang satu sama lain. Perlu disadari juga bahwa norma-norma dan harapan untuk mengirim pesan-pesan nonverbal khususnya sentuhan dan ruang atau jarak pribadi bervariasi antara konteks hubungan dan konteks professional. 
Sementara itu, untuk meningkatkan kompetensi kita mengenai decoding pesanpesan nonverbal, maka kita harus melihat berbagai petunjuk nonverbal. Kita harus menghindari menempatkan terlalu banyak pada salah satu petunjuk dan melakukan evaluasi pesan-pesan nonverbal dalam kaitannya dengan konteks dan pengalaman kita sebelumnya dengan orang lain. Meskipun kita lebih menitikberatkan pada komunikasi nonverbal dibandingkan dengan pesan verbal ketika mendeteksi manipulasi, tidak ada aturan baku yang dapat memungkinkan kita untuk mengatakan bahwa orang lain itu memperdayakan atau tidak.

\subsubsection{Jenis Komunikasi Non Verbal}

Sebagaimana bahasa verbal yang dapat diklasifikasikan ke dalam beberapa jenis, begitu pula dengan komunikasi nonverbal. Komunikasi nonverbal dapat dikategorikan ke dalam beberapa jenis, yaitu :

- Kinesik - studi tentang gerakan tubuh termasuk postur tubuh. Kinesik memiliki beberapa komponen yaitu gesture tubuh, gerakan kepala, kontak mata, dan ekspresi wajah.

- Proksemik - studi tentang penggunaan ruang dan jarak dalam komunikasi manusia.
- Kronemik - disebut juga dengan komunikasi temporal, yaitu cara seorang individu mengorganisasi dan menggunakan waktu dan pesan yang diciptakan. Waktu memiliki dampak terhadap komunikasi, termasuk didalamnya adalah perbedaan siklus waktu, perbedaan antara orang-orang yang berorientasi ke masa depan dan masa lalu, serta perspektif budaya tepat waktu sebagai sesuatu yang tetap dan dapat diukur atau bersifat cair dan mudah diadaptasi.

- Paralinguistik - adalah suara tanpa kata dan karakteristik bahasa tanpa kata seperti pitch, volume, peringkat, dan kualitas

- Artifak - ornamen-ornamen yang diperlihatkan

- Haptik- perilaku menyentuh yang mengirimkan makna selama interaksi. Sentuhan bekerja pada berbagai tingkatan termasuk didalamnya professional-fungsional, sosial-sopan santun, persahabatan-kehangatan, dan cinta-intim.

Sementara itu, untuk meningkatkan kompetensi kita mengenai decoding pesanpesan nonverbal, maka kita harus melihat berbagai petunjuk nonverbal. Kita harus menghindari menempatkan terlalu banyak 
pada salah satu petunjuk dan melakukan evaluasi pesan-pesan nonverbal dalam kaitannya dengan konteks dan pengalaman kita sebelumnya dengan orang lain. Meskipun kita lebih menitikberatkan pada komunikasi nonverbal dibandingkan dengan pesan verbal ketika mendeteksi manipulasi, tidak ada aturan baku yang dapat memungkinkan kita untuk mengatakan bahwa orang lain itu memperdayakan atau tidak. Peran penting komunikasi nonverbal adalah membentuk dan mengelola hubungan interpersonal dalam sistem komunikasi interpersonal. Komunikasi nonverbal membantu memulai hubungan melalui pengelolaan kesan atau impression management dan self-disclosure.

Komunikasi nonverbal juga membantu mengelola hubungan sebagaimana komunikasi nonverbal membantu dalam ekspresi emosi yang diminta dan memberikan dukungan emosi.

Para professional mengindikasikan bahwa komunikasi nonverbal adalah salah satu bagian penting dalam pekerjaan mereka. Para pemimpin organisasi Keterampilan melakukan decoding non verbal untuk berbicara dengan bawahannya ketika berada dalam tekanan dan membutuhkan dukungan. Selain itu, para pemimpin organisasi dapat menggunakan keterampilan encoding untuk mempertunjukkan sensivitas nonverbal. Sinyal-sinyal nonverbal juga dapat membantu dalam pengelolaan kesan dalam bidang professional. Meskipun banyak dari sinyal nonverbal yang tampak lebih halus dan universal secara universal, beberapa diantaranya disadari sangat berbeda diantara kebudayaan, khususnya dalam proksemik, kontak mata, dan sentuhan. Adalah lebih baik untuk mengembangkan lebih banyak pengetahuan umum tentang bagaimana norma-norma nonverbal berbeda berdasarkan nilai-nilai budaya dan memandang pengetahuan tersebut sebagai alat yang dapat didaptasi untuk digunakan dalam berbagai macam konteks budaya.

Komunikasi nonverbal antara pria dan wanita, sebagaimana aspek-aspek komunikasi lainnya, sejatinya memiliki banyak kesamaan dibandingkan dengan perbedaannya. Hasil penelitian seringkali menunjukkan bahwa bagaimanapun juga gesture wanita, kontak mata, sentuhan, dan berdiri memiliki kesamaan dengan pria. Wanita hanya lebih banyak menggunakan ekspresi wajah dibandingkan pria. 
III. PENUTUP

Komunikasi Verbal memainkan peranan yang sangat penting dalam kehidupan kita ketika kita berkomunikasi dengan orang-orang yang kita temui. Komunikasi nonverbal adalah sebuah proses menggunakan pesan-pesan tanpa kata untuk menyamakan makna. Studi ilmiah pertama tentang komunikasi nonverbal dapat kita ketahui melalui buku Charles Darwin, sang penemu teori evolusi. Dalam bukunya ia berpendapat bahwa semua mamalia menunjukkan emosi melalui raut wajah. Emosi merupakan salah satu bentuk komunikasi nonverbal yang menggambarkan pentingnya arti komunikasi apapun konteksnya.

Berikut adalah beberapa pengertian tentang komunikasi nonverbal menurut beberapa ahli, diantaranya adalah :

- Judee Burgoon mendefinisikan komunikasi nonverbal sebagai perilaku selain kata-kata yang membentuk sistem koding secara sosial, karenanya komunikasi nonverbal dikirimkan secara intens dan diinterpretasi secara intens, yang digunakan diantara anggota komunitas bicara secara regular, dan interpretasi dapat disadari secara sepakat.
- Judy Pearson, dkk mendefinisikan komunikasi nonverbal sebagai sebuah proses penggunaan pesan tanpa kata yang menimbulkan makna.

- K. Floyd (2009) mendefinisikan komunikasi nonverbal sebagai setiap perilaku dan karakteristik yang mengirimkan makna tanpa menggunakan kata-kata.

- Mark L. Knapp dan J.T. Hall (2002) menyatakan bahwa komunikasi nonverbal merujuk pada komunikasi yang dihasilkan oleh beberapa makna lain selain kata-kata. Menurut Mark L. Knapp, Judith T. Hall, dan Terrence G. Horgan (2014 : 4), komunikasi nonverbal memiliki 3 (tiga) aspek utama, yaitu :

- Mengirim pesan-pesan nonverbal.

- Menerima pesan-pesan non verbal.

- Hubungan yang kompleks antara pengirman dan penerimaan pesanpesan non verbal.

Komunikasi ada dimana-mana : dirumah, di kampus, di bioskop bahkan dimanapun. Komunikasi menyentuh segala aspek kehidupan kita. Sebuah penelitian mengungkap $70 \%$ waktu bangun kita digunakan untuk berkomunikasi. Komunikasi menentukan kualitias hidup kita. 


\section{DAFTAR PUSTAKA}

Aminudin, 2007. Peran Rumah dalam

Kehidupan Manusia Kanisius.

Semarang: Rineka Cipta

Arikunto, 2005. Prosedur Penelitian Suatu

Pendekatan Praktik. Jakarta: PT

Rineka Cipta

Anton Rianto. 2005. Born to Win: Kunci Sukses yang Tak Pernah Gagal. Jakarta: Gramedia Pustaka Utama.

Ary, Agustian Ginanjar. 2007. ESQ Power Sebuah Inner Journey Mealui Al-Ihsan. Jakarta: Arga.

Black, James A.dan Dean J. Champion. 1999. Metode dan Masalah Penelitian Sosial. Bandung: Rapika Aditama.

Cangara, H. Hafied. (2013) Perencanaan dan Strategi Komunikasi. Jakarta : PT Raja Grafindo Persada

Campbell, Tom. 1994. Tujuh Teori Sosial: Sketsa, Penilaian-Perbandingan. Yogyakarta: Kanisius.

Chulsum, Umi. Dkk, 2009. Kamus Besar Bahasa Indonesia. Surabaya: Yoshiko Press.

Collin, Finn. 1997. Social reality. London and New York: Routledge..

Effendy, Onong Uchjana.2008. Dinamika Komunikasi. Bandung : Remaja Rosdakarya

Gantiano, H. E. (2019). FENOMENA FACEBOOK SEBAGAI SARANA KOMUNIKASI SOSIAL. Dharma
Duta.

https://doi.org/10.33363/dd.v15i1.163

Hasan, Muhammad Tholchah. 2000. Dinamika Kehidupan Religius. Jakarta: PT. Listafariska Putra.

Kalianda, Deri. 2018. Strategi Komunikasi Dinas Lingkungan Hidup (Dlh) Dalam Mengimplementasikan Program Green City Di Kota Teluk Kuantan Kabupaten Kuantan Singingi. Universitas Riau

Lamintang, 2009. Delik-delik Khusus Kejahatan terhadap Harta Kekayaan. Jakarta: Sinar Grafika

Laudjeng. 2003. Hukum adat indonesia. Jakarta: Gramedia Widiasana Indonesia.

Macionis, J. J. (1997). Sociology: Sixth edition. New Jersey, Prentice Hall, Upper Saddle River

Moeljatno. 2009. Kitab Undang-Undang Hukum Pidana. Jakarta: Bumi Aksara

Moleong, 2007, Metode Penelitian Kualitati, Bandung: Remaja Rosdakarya.

Mulyatinigsih, Endang. 2012. Metode Penelitian Terapan Bidang Pendidikan. Bandung: Alfabeta

Nasution, S. 2003. Metode Research. Jakarta. Bumi Aksara

Mulyana, Deddy. \& Solatun. 2008. Metode Penelitian Komunikasi. Bandung: PT. Remaja Rosdakarya. 
Naufal, Abdur Razak, 1993. Allah dari Segi Ilmu Pengetahuan Modern alih bahasa Halimuddin. Surabaya: Bina Ilmu

Nugrahni, Ardika Dwi. 2013. Religiusitas Dengan Motivasi Belajar. Surakarta : Universitas Muhammadiyah Surakarta

Nur Illah. 2013. Hubungan Motivasi Beribadah dengan Pengalaman Beragama. Yogyakarta : UIN Kalijaga

Ramayulis. 2013. Psikologi Agama. Jakarta: Kalam Mulia

Samsudin, Ali. 2009. Manajemen Sumber Daya Manusia. Bandung : CV Pustaka Setia

Sardiman, AM. 2016. Interaksi dan Motivasi Belajar Mengajar. Jakarta: Rajawali Press.

Sari, Novita. 2015. Peran Guru Dan Orang Tua Dalam Memotivasi Ibadah Sholat Wajib Siswa Di Mts Negeri Pucanglaban. Surabaya : IAIN Tulung Agung

Soekanto, Soerjono. 2007. Sosiologi suatu Pengantar. Jakarta: P.T.Raja Grafindo

Wirawan 2007, Budaya dan Iklim Organisasi; Teori Aplikasi dan Penelitian,penerbit salemba empat.

Yasin, Ali. 2013. Komunikasi Persuasif Fasilitator. KIE RMC III. Jawa Barat

Yusuf Zainal Abidin, 2015. Manajemen Komunikasi (Filosofi, Konsep, dan Aplikasi) Bandung: Pustaka Setia 